\title{
Learning abdominal imaging
}

\author{
A. Luna • J.C. Vilanova ・ P.P. Ros (Eds.)
}

\section{Springer Heidelberg Dordrecht London New York, 2012 ISBN: 978-3-540-88002-8 e-ISBN: $978-3-540-88003-5$}

Published online: 16 March 2013

(C) Springer-Verlag 2013

This book in its 256 pages is intended to give the reader a review of cases devoted to abdominal imaging, addressing in ten sections: Liver; Gallbladder and Biliary System; Pancreas; Spleen; Peritoneum; Esophagus; Stomach and Duodenum; Small Bowel; Colon; Rectum-Anus. Ten cases have been chosen for each section, simple as well as complicated or unusual cases highlighting the topic, cases which should and could be of practical use to both physicians in training as well as expert radiologists.

Each case is presented following a fixed framework which presents on the first page radiological images, primarily CT, MRI or US and on the facing page a very short clinical history, extended comments about the condition and pertinent imaging findings. This layout makes one wonder: why do comments anticipate the imaging findings? It would have been better - at least in my opinion - exactly the contrary.

At the end of each ten-case section one will find one page of selected references (books; websites; articles) in order to expand the reader's knowledge on the topic.

Images are of the highest quality and properly chosen however, sometimes arrows are missing. Very few misprints were found in the text and no index is to be found at the end.

Anyway a useful book to be at hand in daily practice.
Intenzione di questo volume nelle sue 256 pagine è di offrire al lettore una serie di casi interessanti lo studio per immagini dell'addome, divisi in dieci sezioni dedicate: Fegato, colecisti ed albero bilaire; Pancreas; Milza; Peritoneo; Esofago; Stomaco e duodeno; Intestino tenue; Colon; Retto ed ano. Per ogni sezione sono stati selezionati dieci casi, sia semplici che complicati od inusuali, ben illustranti l'argomento, casi che dovrebbero e potrebbero essere di utilità pratica sia ai medici in tirocinio che ai radiologi esperti.

Ogni caso è presentato seguendo uno schema determinato, caratterizzato da una prima pagina con le immagini radiologiche, fondamentalmente TC, RM o US e, sulla pagina a fronte, da una storia clinica molto succinta ed un'ampia epicrisi corredata da immagini diagnostiche pertinenti. $D i$ fronte a questa impostazione ci si chiede: perché i commenti precedono i reperti per immagini? Sarebbe stato meglio, almeno secondo la mia opinione, disporre esattamente del contrario.

Al termine dei dieci casi di ogni sezione, si trova una pagina di riferimenti selezionati (libri, websites, articoli), in modo tale da poter ampliare le conoscenze del lettore sull'argomento.

Le immagini sono della più elevagta qualità e scelte con cura: tuttavia, talvolta, mancano delle opportune frecce indicatrici. Sono stati trovati alcuni errori di stampa e infine il volume non è corredato da un indice.

Si tratta comunque di un utile supporto di cui disporre nell'attività quotidiana. 